\title{
High Exhaustion of Chrome Tan, Enhancement of Leather Properties and Reduction of Chrome Tanning Effluent Impact
}

\author{
EL-Shahat H.A. Nashy ${ }^{1^{*}}$ and Kamal A. Eid ${ }^{2}$ \\ ${ }^{1}$ Chemistry of Tanning Materials and Leather Technology Department, National \\ Research Centre, 33 El-behoose St., Dokki, Cairo, Egypt. \\ ${ }^{2}$ Spectroscopic Dept., National Research Centre, 33 El-behoose St., Dokki, Cairo, \\ Egypt.
}

$\mathbf{T}$

THE LEATHER industry faces very challenging task because of the regulations enforced by the various pollution control bodies to maintain the discharged norms of the chemical in the treated water. From an environmental stand point, one of the most significant waste is the chromium species because it posses a serious disposal problem to human health and the environment. Therefore, chrome tan effluent is critically analyzed for the harmful effects due to the incomplete exhaustion of the hazardous chrome cations in tanning bath. The paper has focused on the challenges/impacts of chrome tanning effluent and evaluates the alternative treatment options. Reducing agents namely; sodium bisulphite $\left(\mathrm{NaHSO}_{3}\right)$, sodium thiosulphate $\left(\mathrm{Na}_{2} \mathrm{~S}_{2} \mathrm{O}_{3}\right)$ in connection with hydroxy carboxylic acids and /or basifying agents were used to enhance the exhaustion, fixation of chrome tan and shrinkage temperature as well as strength properties of the tanned leather. In addition, the leather quality is one of the important factors taking into consideration. The optimum conditions for exhaustion, fixation, shrinkage temperature as well as leather quality showed that both $\mathrm{NaHSO}_{3}$ and $\mathrm{Na}_{2} \mathrm{~S}_{2} \mathrm{O}_{3}$ have a similar effect in connection with basic oxide of $1.5 \%$ magnesium oxide (most effective one) and the best modifying agent is tartaric acid $(3 \%)$, temperature of $35^{\circ} \mathrm{C}$. The best results obtained are $93.51 \%$ exhaustion, $93.71 \%$ fixation and $121^{\circ} \mathrm{C}$ shrinkage temperature in aqueous medium.

The present work was devoted to change the primary condition of tanning process based on the modification of pelt to increase the high exhaustion of chrome tan which consequently, leads to lower the levels of unused chrome in the tanning effluent and minimized the deficit existing from the environmental point of view. The obtained results showed that, over $90 \%$ reduction of the chrome concentration in effluent and $80 \%$ reduction of the COD. The assessment was demonstrated that the modification process exhaust, and fixed of chrome tan, improve leather properties, reduced the environmental impact and at the same time saves energy and time than the traditional one.

Keywords: Environmental impact, Chrome Tan, Reducing agent, Chrome Exhaustion and Fixation, Shrinkage Temperature, Hydroxy carboxylic acid, Basifying agent.

\section{Introduction}

Tanning process is one of the most important steps in tanning industry, in which raw hide is transformed into leather. Chrome tan has proven to be the effective method of tanning and is done in tanneries world wide. It is used for the production of the great majority of various types of leathers such as upper, garments and other light leathers [1]. In all tanning technology operations, in turn, emanate huge composite tanning effluent and solid wastes as well as atmospheric emissions and odours, which discharged in the raw state, without any pretreatment [2]. In average, to process one ton of hide (in wet weight), about 30$40 \%$ of chrome tan does not react with the hide and is thus discharged in the form of spent tanning solution [3].

In general, the chromium wastes from leather processing are the main concern from an environmental stand point, because chrome wastes poses a significant disposal problem to human health and the environment [4-6].

*Corresponding author e-mail: nashy_eha@yahoo.com

DOI: 10.21608 /ejchem.2018.4393.1387

C2017 National Information and Documentation Center (NIDOC) 
The sludge contains a high level of $\mathrm{Cr}$ (III) concentration as 3000-6000 mg/L and must be treated as hazardous solid waste; this usually costs very much [7]. As a result, the sludge is normally disposed unsafely, imposing great hazards to the environment, and wasting valuable chromium [8]. Trivalent chromium is low toxic whilst hexavalent chromium is very toxic for both plant and animal life $[6,9]$. Hexavalent chromium was determined in a mixture of $\mathrm{Cr}$ (III) and $\mathrm{Cr}$ (VI) in some Egyptian tanneries [10].

The pollution due to chromium is one of the major constraints in the leather processing operation. Where, under normal conditions chromium tan are not completely taken up from tanning bath. Therefore, they can be a serious source of pollution in tannery waste effluent. In the absence of adoption of suitable technological methods, typical concentrations of chromium in sectional waste streams of chromium tanning yard are in the range of 1700-2500 ppm [11]. This means that, the hazardous pollution of chromium wastes coupled with poor uptake of chromium during tanning process have challenged the continued use of this process $[12,13]$.

Several technologies for better management of chromium in tanneries[4,5,12,13] have been devoted through; high exhaustion, recovery and recycling, using alternative to chromium salts and safe utilization and disposal of chromium bearing wastes. Chrome recovery and reuse methods have become the compulsory recovery methods in the leather industry to recover and reuse the chromium present in the effluent [14]. Direct or indirect chromium recycling or recovering cannot eliminate completely from effluent coming from post tanning section. Some studies improve exhaustion of chrome tan depend upon using organic solvent as a medium for tanning process [11] or a comination with another tanning agent as aluminum tan [15]. The study was cocern to cleaner technologies used to reduce chromium in waste water based on high exhaustion process. This meaning that, more complete exhaustion of chrome tan leads to lower the levels of unused chrome in the effluent and consequently, less pollution. While, other many trials were carried out to increase the uptake of chrome from tanning bath by changing the primary conditions of tanning [11,16-20].

Thus, the present work was introduced as an alternative method to the traditional tanning method at an industrial level, based on principle Egypt.J.Chem. 62, No. 3 (2019) of prevention is better than treatment, which aims at studying the conditions that enhance exhaustion and fixation of chrome tan as well as improvement of physico-chemical properties of the tanned leather. The method is based on pre-treatment of pickled hide by different basifying agents and/or modification of delimed hide by different hydroxy carboxylic acids in connection with two reducing agents. In general, this study is an attempt aiming towards zero discharge of pollution and at same time improves the leather properties.

\section{Experiments}

Materials

- Egyptian Local bovine hide was selected for this study, which supplied by El-Radio tannery.

- Basic Chromium Sulphate (BCS) of 33\% basicity (Bayer, Germany) was used as a chrome tan.

- Sodium bisulphite, Sodium thiosulphate, Magnesium oxide, Manganese dioxide, Sodium bicarbonate, Citric acid, Tartaric acid and Malic acid of analytical grade were used.

Methods

Sample Preparation

Samples under investigation were Egyptian bovine hide. The samples were worked up in the beam-house operation as usual. The hides were taken as pickled and/or as delimed, but modification was carried out on delimed hide by hydroxyl carboxylic acids, and finally tanned by BCS. Sodium formate (1\%) was added to the mixture before addition of BCS. Slow additions of the reagents were done. Leather samples were $5 \times 7 \mathrm{Cm}$.

\section{Chrome Exhaustion}

Chrome exhaustion was determined by two methods:

A- Measurement of the chrome content in the tanning bath effluent after the tanning process by Atomic Absorption Spectrometer, Varian - Spectra AA220.

B- Determination of chrome in tanned leather by conventional method and Egyptian Specifications (ES 122 \& ES 123) [Official Methods of Analysis, Egyptian Standard Specification][21-23].

\section{Chrome Fixation}

A piece of tanned sample was placed in 100 $\mathrm{mL}$ distilled or de-ionized water for 3 days, then the released chromium in the solution was determined by Atomic Absorption Spectrometer, Varian - Spectra AA220. 


\section{Shrinkage Temperature}

Shrinkage temperature (Ts) is the temperature at which the hide has a significant shrinkage when it is exposed to a heating medium. The rise in shrinkage temperature of the tanned hide indicated the good effect of tanning agent. It was measured according to the conventional method and Egyptian Specification (ES 122) [21-24].

\section{Tanning Process}

Tanning process was carried out under different conditions in presence of two reducing agents; namely, sodium bisulphite $\left(\mathrm{NaHSO}_{3}\right)$ and sodium thiosulphate $\left(\mathrm{Na}_{2} \mathrm{~S}_{2} \mathrm{O}_{3}\right)$ as follows:$A$ - Tanning in the presence of reducing agents 1- Sodium Bisulphite (NaHSO$)_{3}$ ) with basifying agents

The following procedure was applied on each group by using one of the basifying agents $\mathrm{MgO}$ (4\%), $\mathrm{MnO}_{2}(5 \%), \mathrm{MgO}+\mathrm{MnO}_{2}(2.5 \%+2.5 \%)$ and $\mathrm{NaHCO}_{3}(3 \%)$.

Pickled hides in each method were adjusted at $\mathrm{pH}=2.5$, then, $1 \%$ of sodium formate and $12 \%$ of chrome tan were added (twice). Different percent of $\mathrm{NaHSO}_{3}(0.5,1,1.5,2,2.5$ and $3 \%)$ were used at $35^{\circ} \mathrm{C}$ and $15.0 \mathrm{rpm}$ for 23 hours. After that, one of the basifying agents was added and continuous shaking was done for another one hour.

\section{2- Sodium Bisulphite (NaHSO$)_{3}$ with Hydroxy} Carboxylic acids

In this case, the procedures were carried out on each group by using one of the hydroxy carboxylic acids as a modifying agent, tartaric acid (3\%), citric acid (4\%) and malic acid (5\%). The delimed hides were adjusted at $\mathrm{pH} \cong 8.5$, then, the organic acid was added at $35^{\circ} \mathrm{C}$ and $15.0 \mathrm{rpm}$ for $1 \mathrm{hr}$. Sodium formate $(1 \%)$, chrome tan $(12 \%$, twice), and one of the following percentages $(0.5$, $1,1.5,2,2.5$ and $3 \%$ ) of $\mathrm{NaHSO}_{3}$ were added. The shaking was continued for 23 hours under the same conditions.

\section{3- Sodium Thiosulphate $\left(\mathrm{Na}_{2} \mathrm{~S}_{2} \mathrm{O}_{3}\right)$ as a reducing agent}

The above two procedures were repeated using $\mathrm{Na}_{2} \mathrm{~S}_{2} \mathrm{O}_{3}$ instead of $\mathrm{NaHSO}_{3}$.

(B) High-Exhaustion Tanning System (Basification after tanning with the modified skin):

(1)- Chrome tanning with tartaric acid followed by $\mathrm{MgO}$ basification

The delimed hide sample was modified by $3 \%$ tartaric acid (most effective one) then tanning with chrome tan was carried out under the previous optimum conditions. After 23 hours different percentages of $\mathrm{MgO}(0.2,0.5,1,1.5,2,2.5,3$ and $4 \%$ ) were added for each piece under continuous shaking for another one hour.

(2)- Chrome tanning in the presence of $\mathrm{NaHSO}_{3}$ with tartaric acid followed by $\mathrm{MgO}$ basification

The above described tanning procedure was repeated using 3\% tartaric acid and the optimum percent of $\mathrm{MgO}(1.5 \%)$ under different percentages of $\mathrm{NaHSO}_{3}(0.5,1,1.5,2,2.5$ and $3 \%)$. Sodium bisulphite was added at the beginning of the tanning process.

(3) Chrome tanning in the presence of $\mathrm{Na}_{2} \mathrm{~S}_{2} \mathrm{O}_{3}$ with tartaric acid followed by $\mathrm{MgO}$ basification:

The previous procedure was repeated by using $\mathrm{Na}_{2} \mathrm{~S}_{2} \mathrm{O}_{3}$ instead of $\mathrm{NaHSO}_{3}$.

\section{Flame Atomic Absorption Spectrometer}

The total chromium was measured using atomic absorption spectrometer. Atomic absorption spectrometric measurements were carried out using a Varian atomic absorption spectrometer model Specter AA 220. Acetylene/ nitrous oxide flame was used with fuel flow rate of $4.51 \mathrm{~min}^{-1}$ and oxidant flow rate of $3.51 \mathrm{~min}^{-1}$. Chrome was measured in the peak height mode at $357.9 \mathrm{~nm}$ and deuterium background correction was applied to correct for background fluctuation. The detection limit achieved with this line at the used operating conditions was $9.07 \mu \mathrm{g} \mathrm{mL}^{-1}$ with a linear dynamic range between 0.1 and $10 \mu \mathrm{g} \mathrm{mL}^{-1}$.

Water analysis was conducted according to Standard Methods for Examination of Water and Wastewater [APHA, 21st edition, 2005] [25].

\section{Results and Discussion}

This study aims at increasing the uptake of chrome tan by changing the primary conditions of tanning process, using two reducing agents in connection with different conditions. The shaking rate was carried out at $15.0 \mathrm{rpm}$ due to; the transportation of chromium ions into the fiber structure is an important pre-condition prior to tanning [26]. The mechanical action serves to flex the hide and create forces required to pump chromium into the fiber structure [5], and consequently the chemical reactions between chromium and hide protein take place.

The initial tanning $\mathrm{pH}$ was 2.5 , this is attributed to the fact that chromium tanning salts having a valence of +3 are soluble in strong acids but usually precipitate as chromium hydroxide or hydrated chromium oxide, at $\mathrm{pH}$ values above

Egypt.J.Chem. 62, No. 3 (2019) 
4.0 [5,27]. In addition, initial $\mathrm{pH}$ greater than 2.5 leads to the formation of too large complexes, which impede the complexes diffusion into the hide [11]. The optimum conditions for most chrome tan exhaustion and fixation were studied as follow:

Effect of Reducing Agents Concentration under Basification and Modification

To determine the most suitable conditions for enhanced exhaustion and fixation of chrome tan, two reducing agents were used in connection with basic medium and /or modified skin by hydroxy carboxylic acids. Sodium bisulphite $\left(\mathrm{NaHSO}_{3}\right)$ and sodium thiosulphate $\left(\mathrm{Na}_{2} \mathrm{~S}_{2} \mathrm{O}_{3}\right)$ with different percentages $(0.5,1,1.5,2,2.5$ and $3 \%)$ were used.

It was found from Tables $1 \& 2$ that the exhaustion, fixation and shrinkage temperature were improved by increasing the concentration of the two reducing agents $\left(\mathrm{NaHSO}_{3 \&} \mathrm{Na}_{2} \mathrm{~S}_{2} \mathrm{O}_{3}\right)$ under both conditions (modification and basification). The order of basifying agents with both two reducing agents was found to be $\mathrm{MgO}, \mathrm{NaHCO}_{3}$,
$\mathrm{MgO}+\mathrm{MnO}_{2}$ and $\mathrm{MnO}_{2}$, respectively. Also, the order of modifying agents was tartaric acid, citric acid and malic acid, respectively. Shrinkage temperature is used as an important confirmation of the effect of the tanning agent. The optimum concentration of $\mathrm{NaHSO}_{3}$ and $\mathrm{Na}_{2} \mathrm{~S}_{2} \mathrm{O}_{3}$ was found to be $3.0 \%$, while that, the basifying agent was $\mathrm{MgO}$ as the most effective one and tartaric acid as the best modifying agent.

The reaction between chrome tan and hide protein will result in stabilizing the fiber by cross linking. The degree of stabilization is conveniently measured by the shrinkage temperature of the tanned hide. The rise in shrinkage temperature of the tanned hide indicated the good effect of tanning agent which is resulting from the improvement of exhaustion and fixation of chrome tan. Furthermore, it is noticed that, exhaustion and fixation of chrome tan and shrinkage temperature in presence of two reducing agents are greater than those in their absence, as shown in Fig. 1-3.

Increasing exhaustion and fixation of

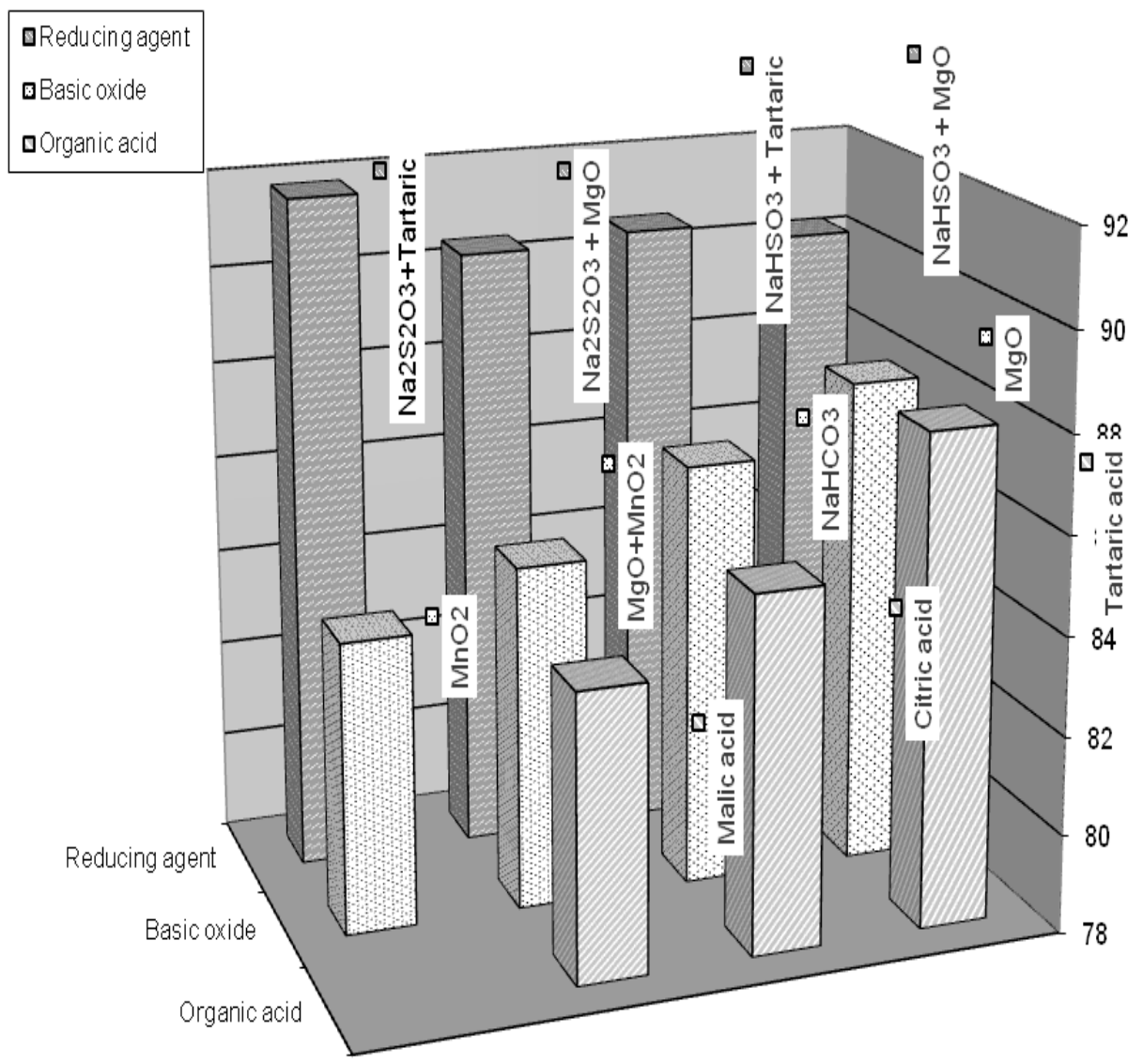

Fig. 1. Effect of reducing agent on Exhaustion compared with basic oxides and hydroxy organic acids. 


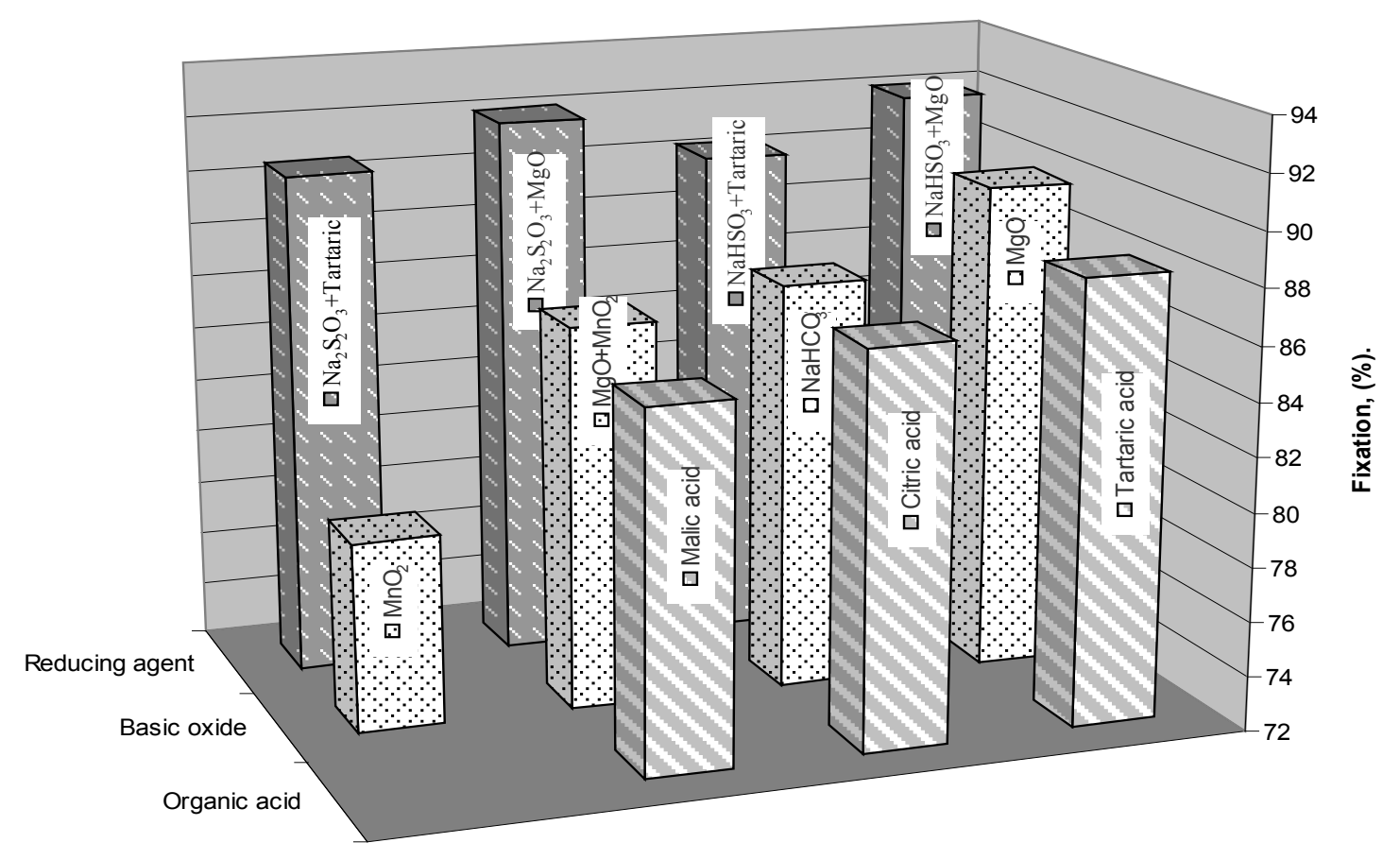

Fig. 2. Effect of reducing agent on fixation compared with basic oxides and hydroxy organic acids.

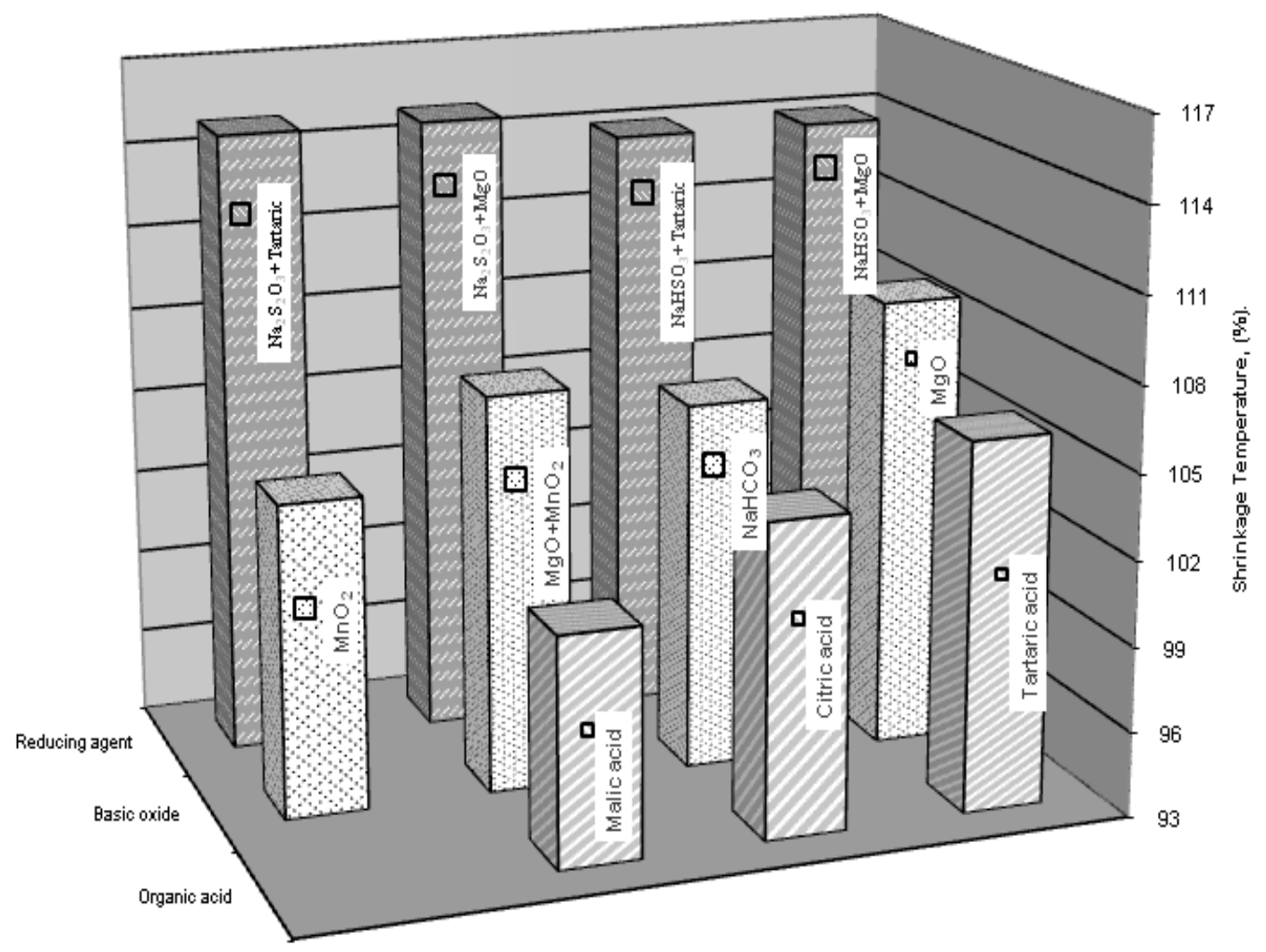

Fig. 3. Effect of reducing agent on Shrinkage Temperature compared with basic oxides and hydroxy organic acids. 
chrome tan could be demonstrated due to the less probability of chromium species formation for oxidation states greater than +3 during tanning which is expected to inhibit the tanning process due to its low affinity to the hide proteins.
The effect of each of $\mathrm{NaHSO}_{3}$ and $\mathrm{Na}_{2} \mathrm{~S}_{2} \mathrm{O}_{3}$ in connection with various bases and hydroxy organic acids are shown in Fig. 4-6. The slight improvement of exhaustion, fixation and shrinkage temperature by using $\mathrm{Na}_{2} \mathrm{~S}_{2} \mathrm{O}_{3}$ than of $\mathrm{NaHSO}_{3}$ is due to the slightly greater reducing efficiency of $\mathrm{Na}_{2} \mathrm{~S}_{2} \mathrm{O}_{3}$ than that of $\mathrm{NaHS}\left[\left[\mathrm{O}_{3}\right.\right.$.

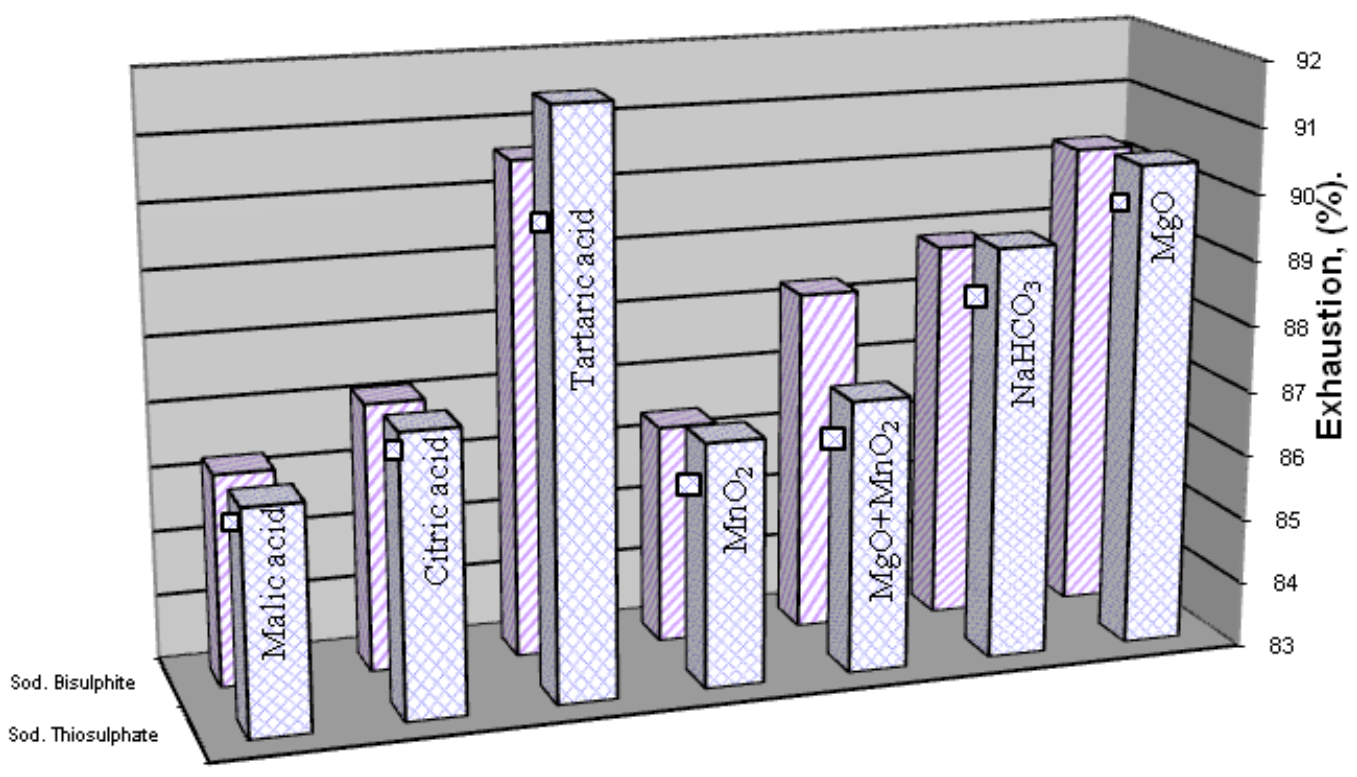

Fig. 4. Effect of reducing agent on Exhaustion in connection with basic oxides and hydroxy organic acids.

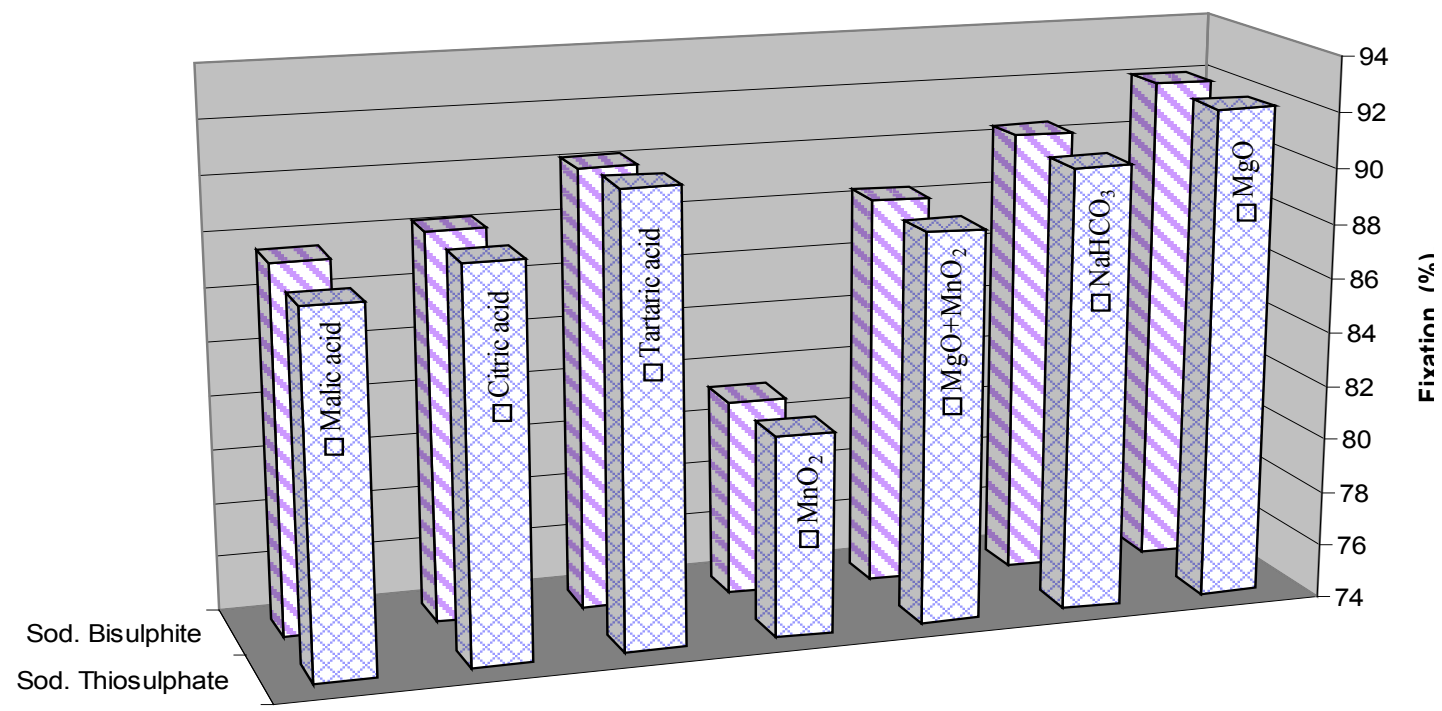

Fig. 5. Effect of reducing agent on fixation in connection with basic oxides and hydroxy organic acids. 


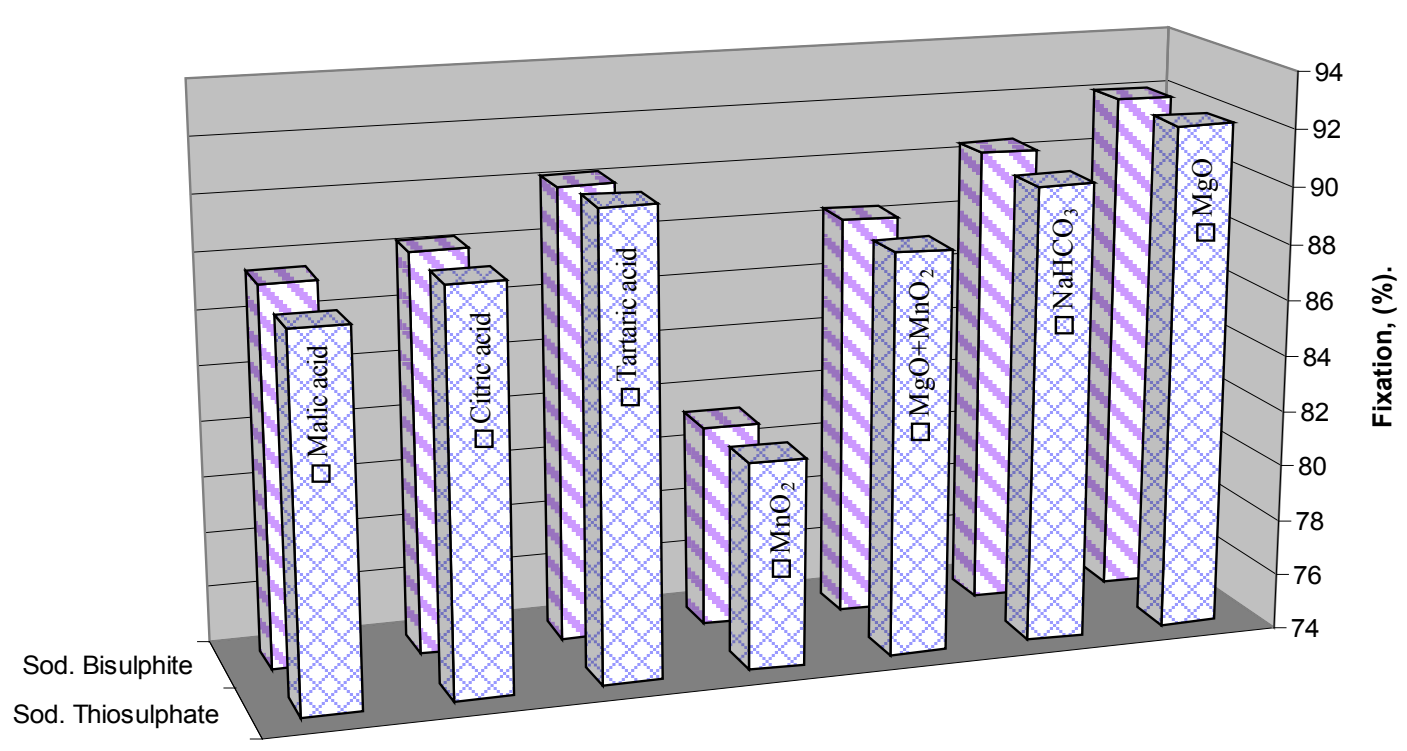

Fig. 6. Effect of reducing agent shrinkage temperature in connection with basic oxides and hydroxy organic acids.

It was observed from Fig. 4-6 that, $\mathrm{MgO}$ is the most suitable basifying agent which gives the most improvement of chrome exhaustion and fixation as well as the highest shrinkage temperature. This could be attributed to the high solubility of $\mathrm{MgO}$ and the rapid development of the basifying agent [28], which lead to release of internally ionized carboxyl groups to form a complex with chrome tan. With $\mathrm{MgO}$, leather has good uniformity of color, good shrink tests and uniform $\mathrm{pH}$.

Also, tartaric acid was found to be the most suitable modifying agent leading to the most optimum results. The hydroxy carboxylic acid introduces additional carboxyl groups to the hide protein, where the hydrogen atom of the hydroxyl group in the acid is bound to the nitrogen atom in the side chain amino groups of collagen. So, the chance of chrome to form complex will increase, (Scheme 2). Since the increased reactivity of chrome tanned pelt by tartaric acid (additional carboxylic groups) lead to the complex formation with chrome/ collagen compound.

\section{Effect of $\mathrm{MgO}$ Concentrations after Modification} by Tartaric Acid:

Table 1 illustrates the effect of $\mathrm{MgO}$ with tartaric acid on chrome exhaustion, fixation and shrinkage temperature. The delimed hide samples were modified with 3\% tartaric acid then, tanned by chrome tan. Different percentages of $\mathrm{MgO}$ were added in each process. Chrome exhaustion, fixation and shrinkage temperature were increased by increasing $\mathrm{MgO}$ percent up to $1.5 \%$. The mild alkali is sufficient to reduce the acidity of the chrome pelt to an acceptable level leading to increase of chrome complex size that was more able to crosslink with the hide protein.

The improvement of exhaustion, fixation and

TABLE 1. Effect of MgO concentration on exhaustion and fixation of chrome tan after modifying the skin by tartaric acid.

\begin{tabular}{cccc}
\hline MgO \% & Exhaustion \% & Fixation \% & Ts $\left({ }^{\circ} \mathbf{C}\right)$ \\
\hline 0.2 & 87.80 & 88.29 & 109 \\
0.5 & 88.56 & 89.41 & 112 \\
1.0 & 89.18 & 89.87 & 114 \\
1.5 & 90.05 & 90.19 & 115 \\
2.0 & 83.31 & 83.27 & 110 \\
2.5 & 81.82 & 80.18 & 106 \\
3.0 & 80.29 & 80.69 & 106 \\
4.0 & 78.34 & 79.52 & 103 \\
\hline
\end{tabular}


shrinkage temperature was found to be continued up to the $\mathrm{MgO}$ percentage (1.5\%) above which decreases of exhaustion, fixation and shrinkage temperature were noticed. This decrease is attributed to the increased basicity which leads to the precipitation of some chrome in the bath as chromium hydroxide. Also, the increased basicity above the optimum limit increases formation of the too large chrome complexes which are capable of impeding the chrome diffusion into the hide proteins resulting in decreasing exhaustion, fixation and shrinkage temperature.

Effect of Reducing Agents Concentration with $\mathrm{MgO}$ Basification after Modifying the Skin by Tartaric Acid

From the above results, it was found that the best result was obtained by using $\mathrm{MgO}$ of $1.5 \%$ as a basifying agent and tartaric acid of 3\% as a modifying agent. By using $\mathrm{MgO}$ with tartaric acid in a combination with one of the reducing agents
( $\mathrm{NaHSO}_{3}$ or $\mathrm{Na}_{2} \mathrm{~S}_{2} \mathrm{O}_{3}$ ) the most desired result would be expected.

The tanning process was carried out using tartaric acid and $\mathrm{MgO}$ at the obtained optimum conditions discussed above in presence of different percentages of $\mathrm{NaHSO}_{3}$ or $\mathrm{Na}_{2} \mathrm{~S}_{2} \mathrm{O}_{3}$. The optimum percentage of either $\mathrm{NaHSO}_{3}$ or $\mathrm{Na}_{2} \mathrm{~S}_{2} \mathrm{O}_{3}$ was found to be $3 \%$ at which the highest exhaustion, fixation and shrinkage temperature were noticed. Table 2 shows the effect of $\mathrm{NaHSO}_{3}$ and $\mathrm{Na}_{2} \mathrm{~S}_{2} \mathrm{O}_{3}$ percentages on exhaustion, fixation and shrinkage temperature in presence of $\mathrm{MgO}$ after modification of the skin by tartaric acid.

The obtained results in Table 2 show that exhaustion and fixation of chrome tan were enhanced as well as shrinkage temperature of tanned leather was improved by using one of two reducing agents $\left(\mathrm{NaHSO}_{3}\right.$ or $\left.\mathrm{Na}_{2} \mathrm{~S}_{2} \mathrm{O}_{3}\right)$ in conjugation with modified skin followed by $\mathrm{MgO}$ basification.

TABLE 2. Effect of $\mathrm{NaHSO}_{3}$ and $\mathrm{Na}_{2} \mathrm{~S}_{2} \mathrm{O}_{3}$ concentration on exhaustion and fixation of chrome tan in connection with $\mathrm{MgO}$ basification after modification by tartaric acid.

\begin{tabular}{ccccccc}
\hline & \multicolumn{2}{c}{ Exhaustion, $\%$} & \multicolumn{2}{c}{ Fixation, \% } & \multicolumn{2}{c}{ Shrinkage Temp.Ts $\left({ }^{\circ} \mathbf{C}\right)$} \\
Percente used, \% & $\mathbf{N a H S O}_{\mathbf{3}}$ & $\mathbf{N a}_{\mathbf{2}} \mathbf{S}_{\mathbf{2}} \mathbf{O}_{\mathbf{3}}$ & $\mathbf{N a H S O}_{\mathbf{3}}$ & $\mathbf{N a}_{\mathbf{2}} \mathbf{S}_{\mathbf{2}} \mathbf{O}_{\mathbf{3}}$ & $\mathbf{N a H S O}_{\mathbf{3}}$ & $\mathbf{N a}_{\mathbf{2}} \mathbf{S}_{\mathbf{2}} \mathbf{O}_{\mathbf{3}}$ \\
\hline 0.5 & 90.06 & 89.68 & 89.96 & 89.81 & 114 & 113 \\
1.0 & 90.44 & 90.19 & 90.25 & 90.07 & 116 & 116 \\
1.5 & 91.00 & 91.36 & 91.06 & 90.98 & 118 & 116 \\
2.0 & 92.08 & 91.80 & 92.01 & 91.97 & 119 & 119 \\
2.5 & 92.54 & 92.50 & 92.50 & 92.62 & 119 & 120 \\
3.0 & 93.59 & 93.50 & 93.57 & 93.71 & 120 & 121 \\
\hline
\end{tabular}

\section{Effect of Temperature}

Different values of temperatures $(25,27.5$, $30,32,35,40$ and $45^{\circ} \mathrm{C}$ ) were applied for chrome exhaustion, fixation and shrinkage temperature under the obtained optimum conditions. Table 3 indicates that chrome exhaustion, fixation and shrinkage temperature were increased by increasing temperature up to $35^{\circ} \mathrm{C}$. The increase of the amount of chrome exhausted with increasing temperature is referred to the increase of the ionization constant of water with increasing temperature which leads to the larger interacting complexes [29]. These larger complexes are more fixed to protein fibers.

Therefore, the rates of penetration as well as fixation increase by increasing temperature as the chemical reactions of chrome with collagen are subjected to thermal activation. The maximum temperature used in this study was $45^{\circ} \mathrm{C}$ as the protein hide undergoes major changes in the lattice order at temperatures above $50^{\circ} \mathrm{C}$ and the rate of chrome diffusion into hide structure increases with a temperature less than $50^{\circ} \mathrm{C}$ [6].

The optimum temperature of tanning by chrome was found to be $35^{\circ} \mathrm{C}$ due to.

1- Improvement of exhaustion, fixation and shrinkage temperature is considerably small by increasing temperature above $35^{\circ} \mathrm{C}$.

2- The hide quality decreases by raising temperature above $35^{\circ} \mathrm{C}$.

3- Upon raising temperature above $35^{\circ} \mathrm{C}$, the consumed energy will be high.

The steady increase of exhaustion, fixation and shrinkage temperature coupled with the hide quality decreasing at temperatures above $35^{\circ} \mathrm{C}$ may be due to an increase in the size of chrome complexes which impede diffusion into the hide, leading to inhomogeneous distribution of chrome [14]. 
TABLE 3. Effect of temperature on chrome exhaustion, fixation and Shrinkage Temperature in presence of $\mathrm{NaHSO} 3$ and $\mathrm{Na}_{2} \mathrm{~S}_{2} \mathrm{O}_{3}$ as reducing agents.

\begin{tabular}{ccccccc}
\hline \multirow{2}{*}{$\begin{array}{c}\text { Temperature, }\left({ }^{\circ} \mathbf{C}\right) \\
\left({ }^{\circ} \mathbf{C}\right)\end{array}$} & $\begin{array}{c}\text { Sod. } \\
\text { Thiosulphate }\end{array}$ & $\begin{array}{c}\text { Sod. } \\
\text { Bisulpite }\end{array}$ & $\begin{array}{c}\text { Sod. } \\
\text { Thiosulphate }\end{array}$ & $\begin{array}{c}\text { Sod. } \\
\text { Bisulpite }\end{array}$ & $\begin{array}{c}\text { Fixation \% } \\
\text { Thiosulphate }\end{array}$ & $\begin{array}{c}\text { Sod. } \\
\text { Bisulpite }\end{array}$ \\
\hline 25.00 & 106 & 108 & 88.00 & 88.20 & 88.00 & 88.20 \\
27.50 & 108 & 111 & 89.00 & 89.35 & 88.89 & 89.00 \\
30.00 & 113 & 113 & 91.00 & 90.50 & 90.50 & 90.80 \\
32.00 & 116 & 117 & 92.00 & 92.50 & 92.40 & 92.00 \\
35.00 & 120 & 121 & 93.57 & 93.71 & 93.59 & 93.50 \\
40.00 & 120 & 120 & 93.98 & 94.10 & 94.00 & 94.10 \\
45.00 & 121 & 121 & 94.30 & 94.40 & 94.15 & 94.25 \\
\hline
\end{tabular}

\section{Mechanical Properties}

Further fundamental criteria for confirmation of the effect of fixed chrome tan with the hide proteins are the improvements of mechanical properties of tanned leather. Mechanical properties were measured for tanned leather under the attained optimum conditions (Table 4). Strength evaluations of tanned leather, including tensile strength, elongation at break and tear strength have been given the greatest consideration of fiber bundles.
It can be seen from Table 4 that, the mechanical properties have been significantly improved according to the increasing exhaustion and fixation of chrome tan. This may be explained as due to the increase of the active sites of protein fibers through additional carboxyl groups by tartaric acid and increasing ionizable carboxyl groups by basic oxides which undergo cross linking with chrome $\tan$ (Scheme 2). Thus, the modification of tanning process leads to more tanned protein fibers would have better mechanical properties than chrome tanned one (Table 4).

TABLE 4. Mechanical properties of tanned Leather under the obtained optimum condition.

\begin{tabular}{cccl}
\hline Tensile Strength, M.Pa & Strain at repture, $\sum \mathbf{R} \%$ & Tear Strength, $\mathbf{K g} / \mathbf{C m}$ & \\
\hline 29.79 & 62.08 & 118.70 & $\mathrm{Na}_{2} \mathrm{~S}_{2} \mathrm{O}_{3}+\mathrm{MgO}+$ Tartaric Acid \\
27.44 & 60.56 & 105.50 & $\mathrm{NaHSO}_{3}+\mathrm{MgO}+$ Tartaric Acid \\
23.04 & 53.36 & 98.70 & $\mathrm{MgO}+$ Tartaric Acid \\
21.09 & 53.15 & 89.75 & $\mathrm{MgO}$ \\
19.68 & 48.88 & 89.75 & Tartaric Acid \\
17.75 & 39.00 & 81.88 & Traditional \\
\hline
\end{tabular}

\section{Environmental Point of View}

Tanning technology operations produce a huge composite tanning effluent and solid wastes as well as atmospheric emissions and odours. Tanneries effluent is currently discharged directly into the domestic sewer network without treatment.

\section{Tannery Effluent Characteristics}

The physico-chemical characteristics of the tanning effluent were determined according to the Standard Methods for the Examination of Water and Wastewater (APHA), $21^{\text {st }}$ edition, 2005. The main characteristics of wastewater were shown in Table 5. The concentration of COD was ranged from 7835 to $3825 \mathrm{mg} / \mathrm{L}$ with an average of 5830 $\mathrm{mg} / \mathrm{L}$, while, average concentration of BOD was $140 \mathrm{mg} / \mathrm{L}$. The average concentration of chromium species was $3844 \mathrm{mg} / \mathrm{L}$. Sulfides concentration ranged from 1870 to $830 \mathrm{mg} / \mathrm{L}$ with an average of $1350 \mathrm{mg} / \mathrm{L}$. The high concentration of chromium and sulfide species affects the biodegradability of effluent. Consequently, chemical modification of hide before tanning is recommended to carry out by this study. 
TABLE 5. Characteristics of Raw Tannery Effluent.

\begin{tabular}{|c|c|c|c|c|c|c|c|c|c|}
\hline Parameters & pH & $\begin{array}{c}\text { COD } \\
(\mathrm{mg} / \mathrm{L})\end{array}$ & $\begin{array}{c}\text { BOD } \\
(\mathrm{mg} / \mathrm{L})\end{array}$ & $\begin{array}{c}\text { TKN } \\
(\mathrm{mg} / \mathrm{L})\end{array}$ & $\begin{array}{c}\text { TSS } \\
(\mathrm{mg} / \mathrm{L})\end{array}$ & $\begin{array}{c}\text { Sulfides } \\
\text { (mg/L) }\end{array}$ & $\begin{array}{c}\text { Chrome } \\
\text { (mg/L) }\end{array}$ & $\begin{array}{l}\text { Sludge } \\
\text { volume } \\
(\mathrm{mL} / \mathrm{L})\end{array}$ & $\begin{array}{l}\text { Sludge } \\
\text { weight } \\
(\mathrm{mg} / \mathrm{L})\end{array}$ \\
\hline $\begin{array}{l}\text { Tannery } \\
\text { Effluent }\end{array}$ & $3.5 \pm 0.2$ & $5830 \pm 2005$ & $140 \pm 60$ & $590 \pm 200$ & $1800 \pm 850$ & $1350 \pm 520$ & $3844 \pm 352$ & $600 \pm 150$ & $1500 \pm 350$ \\
\hline
\end{tabular}

The characteristics of tanning effluent after modifying process

For the purpose of comparison, the characteristics of tanning effluent after modifying process was carried out without primary treatment. It is clear from Table 6 that, COD of effluent removal was $(80.6 \%)$, and chromium concentration reduced $(90.7 \%)$ by the primary treatment of tanning operation. However, the chromium effluent concentration and COD were highly reduced. The meaning that, the study provides a solution to environment concept according to the prevention principle is very better than treatment.

TABLE 6. Effect of modifying process on COD and chromium concentration.

\begin{tabular}{lcccc}
\hline Sample & $\begin{array}{c}\text { COD } \\
(\mathbf{m g} / \mathbf{L})\end{array}$ & $\begin{array}{c}\mathbf{C r} \\
(\mathbf{m g} / \mathbf{L})\end{array}$ & $\begin{array}{c}\text { Sludge volume } \\
(\mathbf{m L} / \mathbf{L})\end{array}$ & $\begin{array}{c}\text { Sludge weight } \\
(\mathbf{m g} / \mathbf{L})\end{array}$ \\
\hline Raw effluent & $5830 \pm 2005$ & $3844 \pm 352$ & $600 \pm 150$ & $1500 \pm 350$ \\
$\begin{array}{l}\text { Effluent after modifying } \\
\text { process }\end{array}$ & $1130 \pm 150$ & $356 \pm 35$ & $310 \pm 105$ & $2120 \pm 450$ \\
\hline
\end{tabular}

\section{Suggested Mechanism}

It is worth to mention here that, according to modern approach of chrome tan mechanism based on thermodynamic and kinetic factors with molecular modeling and HOMO/LUMO energy as well as ATR-FTIR spectra chrome is interacting with carboxyle and amino groups [30]. In the present work the most optimum results obtained by using tartaric acid which was found to be the most suitable modifying agent. This could be attributed to its chemical structure which is characterized by the presence of two hydroxyl groups in its molecule capable of binding with the amino groups of collagen which results in increasing the carboxyl groups available for binding with chrome. Incorporation of additional carboxyl groups into hide protein leads to increase in the number of metal binding sites in collagen and consequently increasing the reactivity of hide protein for the uptake of chrome tan. Fixation and consequently shrinkage temperature of the tanned hide would increase by using tartaric acid as a modifying agent. The reaction of protein with the tartaric acid is shown in Scheme 1.

Tartaric acid has two carboxylic groups which are near to each other (can be considered in ortho position to each other) and can form stable complexes with chrome salt as shown in Scheme 2.

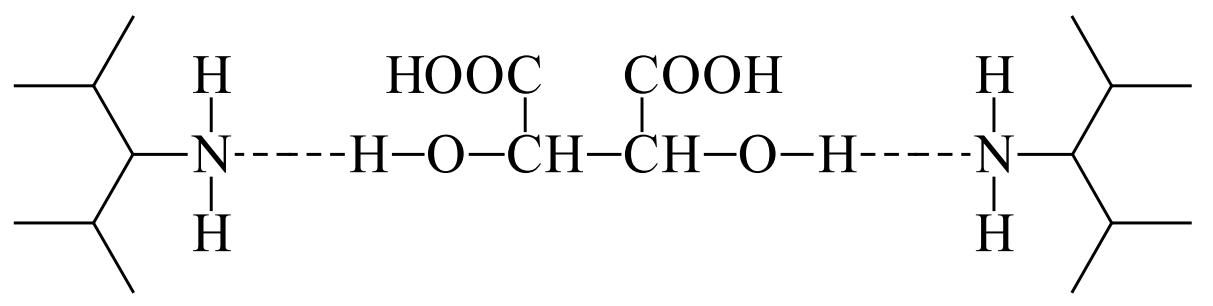

Scheme 1. Reaction of the hydroxyl tartaric acid groups with amino skin groups (modification).

Egypt.J.Chem. 62, No. 3 (2019) 


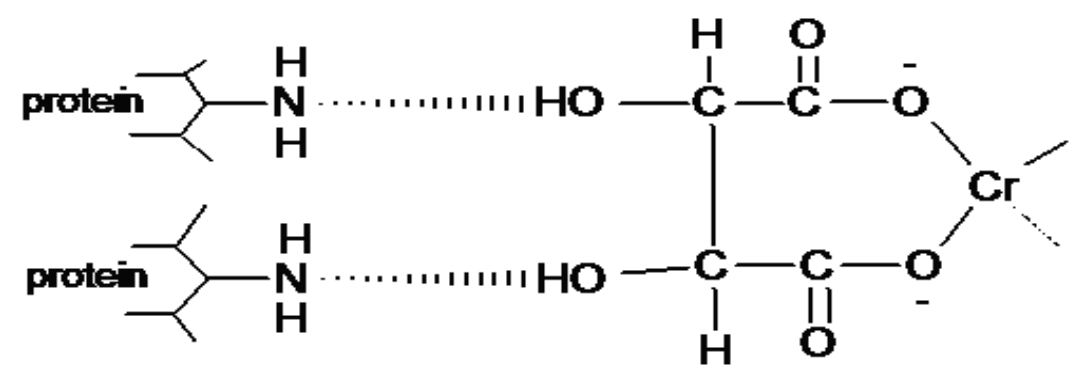

Scheme 2. Chrome attached with carboxyl groups of modified hide by tartaric acidj

This means that tartaric acid treatment modifies the primary amino groups of collagen and consequently increases the efficiency of chrome tan towards the increased number of carboxyl groups. The chrome tan crosslink's with the polypeptide chains by principal valences through coordinative bonds (complex bond) with carboxyl groups of the collagen. Increased fixation as a result of increased exhaustion is due to the fact that increasing exhaustion of $\mathrm{Cr}$ (III) displays a tendency to aggregate and form bridged oligomers of relatively lower solubility and consequently chrome fixation increases. In addition, the initial tanning reaction is dominated by the affinity of the free carboxyl groups for the chromium salt. The slightly alkaline medium increases ionization of the carboxyl groups in hide. These ionized carboxyl groups will be attracted to the chromium atom. When a carboxyl group is not ionized there is little attraction between the protein and chromium atom. The fixation of chromium by the protein increases with the increased ionization of the carboxyl groups.

As tanning proceeds at the suitable basicities, the size of the complex increases, thus permitting the cross-linking. This reaction results in a full tanning and a high shrinkage temperature. Increased shrinkage temperature as a result of increased exhaustion and fixation indicated the increased stabilization of the tanned hide protein as a result of the increased cross-linking by the reaction between the chrome tanning agent and the hide protein.

\section{Summary and Conclusions}

From this study, the results can be summarized in Table 7.

TABLE 7. Optimum effects of tartaric acid modification with MgO on tanning in Connection with two reducing agents.

\begin{tabular}{|c|c|c|c|}
\hline Parameter & $\begin{array}{c}\text { Optimum } \\
\text { exhaustion, \% }\end{array}$ & $\begin{array}{c}\text { Optimum } \\
\text { fixation, \% }\end{array}$ & $\begin{array}{c}\text { Optimum Ts } \\
\left({ }^{\circ} \mathrm{C}\right)\end{array}$ \\
\hline Basification by $\mathrm{MgO}$ & 88.00 & 90.03 & 109 \\
\hline Modification by tartaric acid & 88.00 & 88.32 & 106 \\
\hline $\mathrm{MgO}$ after tartaric acid modification & 90.05 & 90.19 & 115 \\
\hline $\mathrm{MgO}$ after tartaric acid and $\mathrm{NaHSO}_{3}$ & 93.59 & 93.57 & 120 \\
\hline $\mathrm{MgO}$ after tartaric acid and $\mathrm{Na}_{2} \mathrm{~S}_{2} \mathrm{O}_{3}$ & 93.50 & 93.71 & 121 \\
\hline
\end{tabular}

- $\quad$ Magnesium oxide was found to be the best basifying agent used, and the best modifying agent was found to be tartaric acid.

- Combination of tartaric acid modification followed by $\mathrm{MgO}$ basification in the presence of one of the two reducing agents $\mathrm{NaHSO}_{3}$ or $\mathrm{Na}_{2} \mathrm{~S}_{2} \mathrm{O}_{3}$ gave the most improvement of chrome exhaustion, fixation and shrinkage temperature.
- The most favorable conditions in this study for exhaustion, fixation and shrinkage temperature were; $3 \%$ of $\mathrm{NaHSO}_{3}$ and/ or $\mathrm{Na}_{2} \mathrm{~S}_{2} \mathrm{O}_{3}, 3 \%$ of Tartaric acid, $1.5 \%$ of Magnesium oxide and Temperature of tanning bath must not exceed $35^{\circ} \mathrm{C}$.

The following conclusions are derived from the results gained in the endeavored work:

Egypt.J.Chem. 62, No. 3 (2019) 
- Changing the primary conditions of tanning process to improve the chrome exhaustion and fixation and consequently improve the shrinkage temperature and mechanical properties of tanned leather, due to the more fixed chrome through cross-linking with proteins fibers.

- Modification of tanning process was found to be an effective method for chrome tannery effluent than the classical tanning process, which eliminates the chromium salts and sulphide ions and consequently leads to less pollution.

- The chromium tanning effluent causes serious environmental impacts if not properly treated before discharged in the raw state, so modification process minimizes the environmental impact and at the same time saves energy and time.

- Many pollution problems can be overcome based on the principle which says that the prevention is better than treatment

\section{References}

1. Wachsmann H.; World Leather, April 64-65, (2001).

2. Morera J.M., Bacardit A, Ollé L, Bartolí E and Borràs MD.; Minimization of the environmental impact of chrome tanning: a new process with high chrome exhaustion. Chemosphere. 69(11), 1728-33 Nov (2007).

3. Zhen- Ren G., Guangming Z.ng, Jiande F. and Xiudong D.; Enhanced chromium recovery from tanning waste water, J. Cleaner Production, 14, 75-79 (2006).

4. Baig, M.A., Mohsin, M., Shazad M. and Bhatti Z.; Laboratory scale studies on removal of chromium from industrial wastes, J. Environmental Sciences, 15, 417 (2003).

5. Sreeram, K.J. and Ramasami, T.; Sustaining tanning process through conservation recovery and better utilization of chrome, J. Resources Conservation and Recycling, 16, 321 (2002).

6. Alebel Abebe Belay; Impacts of Chromium from Tannery Effluent and Evaluation of Alternative Treatment Options, J. Environmental Protection, 1, 53-58 (2010).

7. Gao Z, Su C.; Treatment of Tannery Waste Water. Beijing Chemical Engineering Publisher (2001).

Egypt.J.Chem. 62, No. 3 (2019)
8. Chuan M. C. and Liu J. C.; Release behaviour of chromium from tannery sludge, Water Res., 30(4), 932-938 (1996).

9. Prokisch J., Katz S.A., Kovacs B. and Gyori Z.; Speciation of chromium from industrial wastes and incinerated sludge's, J. Chromatography A, 774, 363-371 (1997).

10. Eid M.A., Al-Ashkar E.A., Eid K.A., Nashy E.H.A. and Borai E.H.; Speciation of chromium ions in tanning effluents and subsequent determination of Cr (VI) by ICP-AES", J.A.L.C.A., 97, 451- 455 (2002).

11. Silvestre F., Rocrella C., Gaset A., Caruel N. and Darnauld A.; Clean technology for tanning with chromium salts part I, development of a new process in hydrophobic organic solvent media, J.S.L.T.C., 78, 1 (1994).

12. Ramasami, T.; Greening of chrome tanning in Indian leather industry ILIFO, J. Cleaner Tanning, 2, 12 (1996).

13. Chandrasekaran B, Rao J.R., Sreeram K.J., Nair B.U. and Ramasami T.; Chrome tanning sate of art on the material composition and characterization, J. Sci. Ind. Res., 58, 1 (1999).

14. Kanagaraj J., Chandra Babu N.K. and Mandal A.B.; Recovery and reuse of chromium from chrome tanning waste water aiming towards zero discharge of pollution. J. Clean Production. 16, 1807-1813 (2008).

15. Convington, A.D.; The use of aluminum (III) to improve chrome tanning, J.S.L.T.C, 70, 33 (1986).

16. Kedlaya K.J.; Recent technological progress and innovations in the application of chrome in leather making, leather Sci., 21, 1, (1974).

17. Parasad B.G.S., Chandrasekaran B., Rao J.R., Chandrababu N.K., Kanthimathi M. and Ramasami T.; Prospect for chromium management in tanning a critical review, leather Sci., 34, 32 (1987).

18. Nashy E. H. A.; Khedr M. H. and El-Sayed N. H.; Effect of different basifying agents on exhaustion and fixation of chrome tan, Egypt. J. Text. Polym. Sci. Technol., 10 (2), 157-189 (2006).

19. Nashy E. H. A.; Khedr M. H. and El-Sayed N. $\mathrm{H}$.; Improvement of exhaustion and fixation of chrome tan by hydroxy carboxylic acids, Egypt. J. Text. Polym. Sci. Technol., 11(1), 57-70 (2006). 
20. Fuchs K. et al. Economy chrome tanning process with aldehyde-acids and keto-acids US 4715861 A, Publication date Dec 29 (1987). And Economy and plumping chrome tanning, US 5501709 A Publication date Mar 26 (1996).

21. Official Methods of Analysis of the Society of Leather Trades Chemists, 4th Edition, 52, Crouch Hall Lane, Red Bourn. Herts, (1965).

22. Egyptian Standard Specification, Chemical and Biological Tests of Leather, ES 122, (1986).

23. Egyptian Standard Specification, Physical Tests of Leather, ES 122 \& Chemical Tests of Leather ES 123, 2/2, (1986).

24. Stevenson W. T. K. and M. V. Sefton, V.; The equilibrium water content of some thermoplastic hydroxyalkyl methacrylate polymers, J. Appl. Polym. Sci. 36, 1541-1553 (1988).

25. Standard Methods for the Examination of Water and Wastewater (APHA), 21st edition (2005).
26. Germann, H.P.; Chrome tanning from the view point of ecology, J. S.L.T.C., 79, 82 (1995).

27. Thorstenson, T.C.; Practical Leather Technology, Chapter (11), 174, Krieger Publishers Comp., Florida, USA, (1993).

28. Roman P.; The effect of basification on the uptake and distribution of chrome during tannage and the significance of temperature in basification, World Leather, January (2000).

29. Joseph, R.K.; Influence of temperature on the reaction of a chrome tanning solution with calfskin squares, JALCA, 52, 142 (1957).

30. Elshahat H.A. Nashy, Osama Osman, Abdel Aziz Mahmoud, Medhat brahim; Molecular spectroscopic study for suggested mechanism of chrome tanned leather, Spectrochimica Acta Part A: Molecular and Biomolecular Spectroscopy, 88, 171- 176 (2012).

(Received 9/7/2018; accepted 21/10/2018) 
تعظـيم استنفاذ كــــــروم الابـــــــاغة وتعزيز خصائص الجلود و الحد من تأثير النفايات

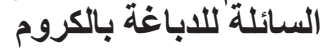

الثحات حسن عبداللطيف ناشي و كمال عيا

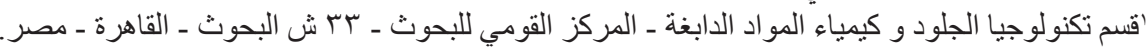

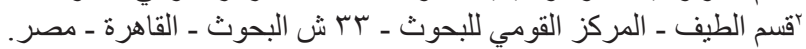

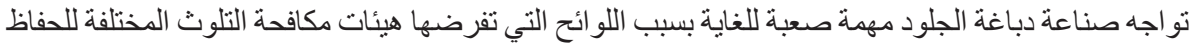

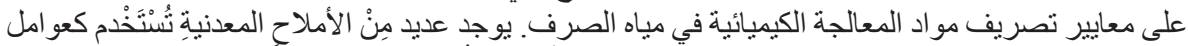

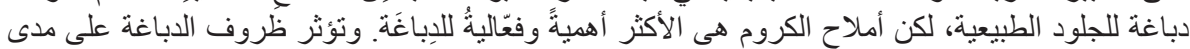

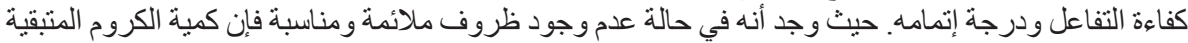

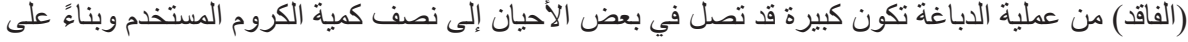

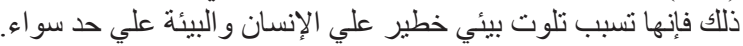

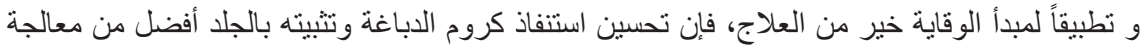

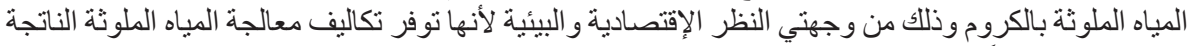
عن الدباغة، فضلاً عن ذللك توفير كمية الكروم المستخدم.

ويهدف البحث إلى دراسة العوامل المؤثرة على استنفاذ وامتصاص الكروم وتثبيته بالجلد بالإضافة إلي الإني

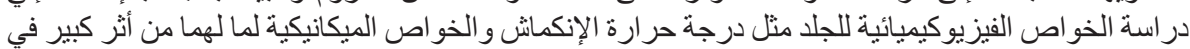

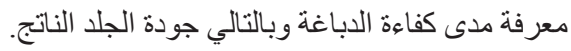

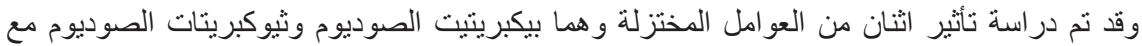

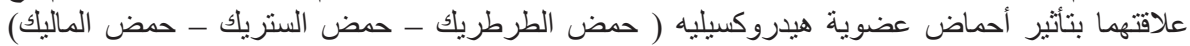

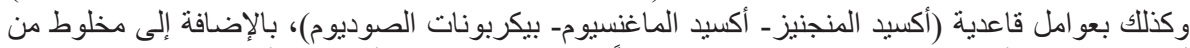

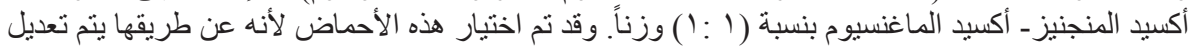

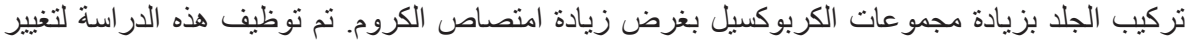

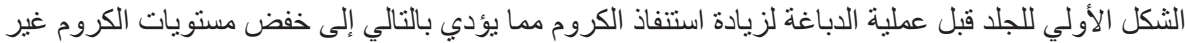
المستخدمة في تدفق الدباغة وتقليل العجز الموجود من البيئة.

ولقد أشارت النتائج التي تم الحصول عليها أنه عن طريق زيادة القاعدية للمحلول بعد تعديل تركيب الجلد

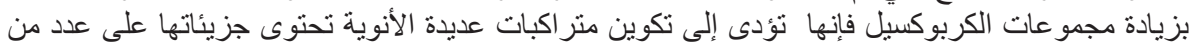
ذر ات الكروم وبالتالي يتم تحسين استنفاذ الكروم. تئي

$$
\text { وقد توصلت الدر اسة إلى النتائج التالية : }
$$

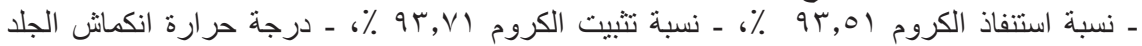

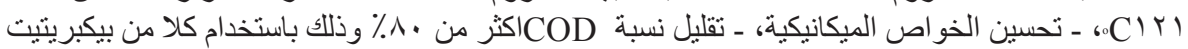

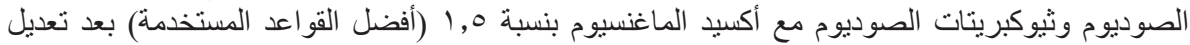
تركيب الجلا باستخدام حمض الطرطريك (أفضل ألأحماض العضوية العيدروكسيليه المستخدمة).

ونتائج هذه الدر اسة توضح أنه عن طريق التحكم في ظروف عملية الدباغة يمكن:

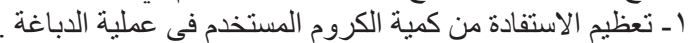

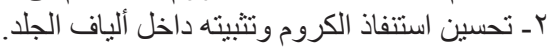

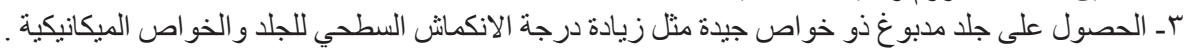

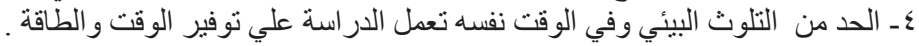

